\title{
Monogeneans from Pangasildae (Siluriformes) in Southeast Asia: X. SIX NEW SPECIES OF THAPAROCLEIDUS JAIN, 1952 (ANCYLODISCOIDIDAE) FROM PANGASIUS MICRONEMA
}

\author{
PARISELLE A.*,*** LIM L.H.S.**** \& LAMBERT A.*****
}

\section{Summary:}

The examination of gill parasites from Pangasius micronema Bleeker, 1847 (Siluriformes, Pangasiidae) in Southeast Asia revealed the presence of nine species of Monogenea. Two (Thaparocleidus brevicochleus Pariselle, Lim \& Lambert, 2001 and T. sinespinae Pariselle, Lim \& Lambert, 2001) have been previously described. Among the others, six species, belonging to Thaparocleidus Jain, 1952 (Monogenea, Ancylodiscoididae) as defined by Lim (1996) and Lim et al. (2001), are considered new species: T. tacitus n. sp., T. summagracilis n. sp., T. portentosus n. sp., T. rukyanii n. sp., T. durandi n. sp., and T. lebrunae n. sp. The remaining species is represented by too few individuals to be conclusively described

KEY WORDS : Monogenea, Ancylodiscoididae, Thaparocleidus tacitus n. sp., Thaparocleidus summagracilis n. sp., Thaparocleidus portentosus n. sp. Thaparocleidus rukyanii n. sp., Thaparocleidus durandi n. sp., Thaparocleidus lebrunae n. sp., freshwater fish, Siluriformes, Pangasiidae, Pangasius micronema, Southeast Asia.
Résumé : Monogènes de Pangasiidae (Siluriformes) en Asie du Sud-EST: X. SiX ESPÈces NOUVELles DE ThaPAROCLEIDUS JaIN, 1952 (ANCYLODISCOIDIDAE) CHEZ PANGASIUS MICRONEMA

L'examen des parasites branchiaux de Pangasius micronema Bleeker, 1847 (Siluriformes, Pangasiidae) en Asie du Sud-Est a révélé la présence de neuf espèces de Monogenea. Deux Thaparocleidus brevicochleus Pariselle, Lim \& Lambert, 2001 et T. sinespinae Pariselle, Lim \& Lambert, 20011 ont déjà été décrites. Parmi les autres, six espèces, appartenant au genre Thaparocleidus Jain, 1952 (Ancylodiscoididae) tel que défini par Lim (1996) et Lim et al. (2001), sont considérées comme nouvelles: T. tacitus $n$. sp., T. summagracilis n. sp., T. portentosus n. sp., T. rukyanii n. sp., T. durandi n. sp. et T. lebrunae n. sp. La dernière espèce est représentée par trop peu d'individus pour être décrite de manière satisfaisante.

MOTS CLÉS : Monogenea, Ancylodiscoididae, Thaparocleidus tacitus n. sp. Thaparocleidus summagracilis n. sp., Thaparocleidus portentosus n. sp., Thaparocleidus rukyanii n. sp., Thaparocleidus durandi $n$. sp., Thaparocleidus lebrunae n. sp., poissons d'eau douce, Siluriformes, Pangasiidae, Pangasius micronema, Asie du Sud-Est.

been described from Pangasius bocourti Sauvage, 1880; $P$. djambal Bleeker, 1846; P. elongatus Pouyaud, Gustiano \& Teugels, 2002; P. gigas Chevey, 1930; P. humeralis Roberts, 1989; $P$. hypophthalmus (Sauvage, 1878); P. kinabatanganensis Roberts \& Vidthayanon, 1991; P. krempfi Roberts \& Vidthayanon, 1991; P. kunyit Pouyaud, Teugels \& Legendre, 1999; P. lithostoma Roberts, 1989; P. mahakamensis Pouyaud, Gustiano \& Teugels, 2002; P. mekongensis Gustiano, Teugels \& Pouyaud, 2003; P. nasutus (Bleeker, 1862); P. nieuwenhuisii (Popta, 1904); P. pangasius (Hamilton, 1822); P. polyuranodon Bleeker, 1852; P. rheophilus Pouyaud \& Teugels, 2000 and P. sabahensis Gustiano, Teugels \& Pouyaud, 2003, from India, Bangladesh, Indonesia, Malaysia, Thailand and Vietnam (see Tripathi, 1957; Lim, 1990, Pariselle et al. 2001a, 2001b, 2002a, 2002b,

\footnotetext{
* IRD (ex ORSTOM), Catfish Asia Project, Instalasi Penelitian Perikanan Air Tawar, Jalan Ragunan-Pasar Minggu, P.O. Box 7220/jkspm, Jakarta 12540 , Indonesia.

*** IRD-CRH, Rue Jean Monnet, BP 171, 34203 Sète Cedex, France. **** Institute of Biological Sciences, University of Malaya, 50603 Kuala Lumpur, Malaysia.

***** Laboratoire Génome, Populations, Interactions, UMR 5171, cc 92, Université Montpellier II, Sciences et Techniques du Languedoc, Place Eugène Bataillon, 34095 Montpellier, Cedex 5, France. Correspondence: A. Lambert. E-mail: Alain.Lambert@univ-montp2.fr
}

2003, 2004a, 2004b, 2005a and 2005b).

\section{MATERIALS AND METHODS}

$\mathrm{F}$ ish (five specimens per locations), caught by hook and line, were bought in fish markets or directly from fishermen in Indonesia (Sumatra 


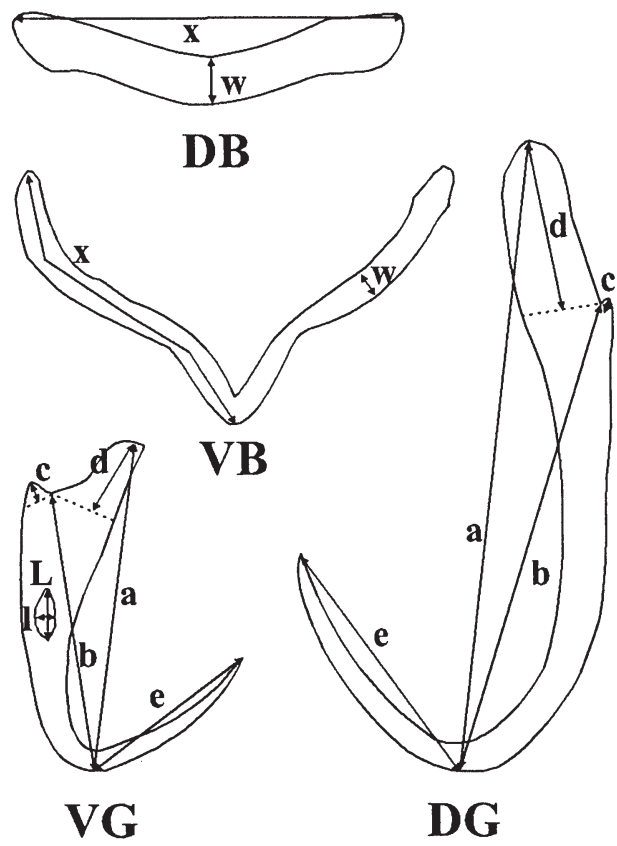

and Borneo) and Malaysia (Borneo). The fish were dissected as soon as possible, and the left branchial arches were frozen in liquid nitrogen, until examination. To verify the specific identity of host fishes, the carcasses were numbered, fixed and preserved in formalin. In the laboratory, the gills were thawed and the monogeneans were detached from the gill using a strong water current. The worms were then transferred individually into a drop of ammonium picrate-glycerine (mixture described by Malmberg (1957)) on a slide with a mounted needle. The preparation was then covered with a round cover slip and sealed with Glyceel (GURR-BDH Chemicals Ltd.). From these preparations, drawings were made of the sclerotised pieces of the haptor and of the copulatory complex using a camera lucida. Measurements, made with a digitiser, in micrometers, and presented as the mean \pm standard deviation followed by the range in parentheses, are those proposed by Gussev (1962) (Fig. 1). The method of numbering of the haptoral pieces is that adopted at ICOPA IV (Euzet \& Prost, 1981). Terminology is that of Pariselle and Euzet (1995) and N'Douba et al. (1999).

\section{RESULTS}

$\mathrm{N}$ ine species of gill Monogenea were recovered in South East Asia from Pangasius micronema (Siluriformes, Pangasiidae). Two have been previously described (T. brevicochleus Pariselle, Lim \& Lambert, 2001 and T. sinespinae Pariselle, Lim \& Lambert, 2001). One is represented by too few individuals (only four among the 902 worms observed) to be conclusively described. The remaining six species are considered new, their anatomy (soft and hard parts) complies with that of Thaparocleidus Jain, 1952 (Monogenea, Ancylodiscoididae) as defined by Lim (1996) and Lim et al. (2001).

\section{DESCRIPTIONS}

\section{THAPAROCLEIDUS TACITUS N. SP. (Fig. 2)}

Type host: Pangasius micronema Bleeker, 1847.

Site: gills.

Type locality: Rajang River at Sibu (Sarawak State, Borneo Island, Malaysia).

Other records: found on the same host in the Kapuas River at Sintang (East Kalimantan Province, Borneo Island, Indonesia) and in the Batang Hari River at Muara Tebo (Jambi Province, Sumatra Island, Indonesia).

Material studied: 30 individuals fixed and mounted in Malmberg solution.

Type material: holotype deposited in the Muséum National d'Histoire Naturelle (Paris): n²73 HG; Ti 240. Paratype deposited in the Muséum National d'Histoire Naturelle (Paris): n²73 HG; Ti 240bis.

Adults: $1324 \pm 359.7$ (472-2107) long, $110 \pm 22.8$ (61170) wide at the level of the penis. Pharynx $58 \pm 7.6$ (40-71) wide. Small dorsal gripus with blade bent at distal third and marked guard: $\mathrm{a}=37 \pm 1.2(34-40)$, $\mathrm{b}=30 \pm 1(28-33), \mathrm{c}=2 \pm 0.6(1-3), \mathrm{d}=11 \pm 1$ (9$13), e=17 \pm 1.2$ (14-19). Small cuneus with very short extension: $\mathrm{L}=9 \pm 0.8(7-11), 1=3 \pm 0.6(2-4), \mathrm{e}=1 \pm$ 


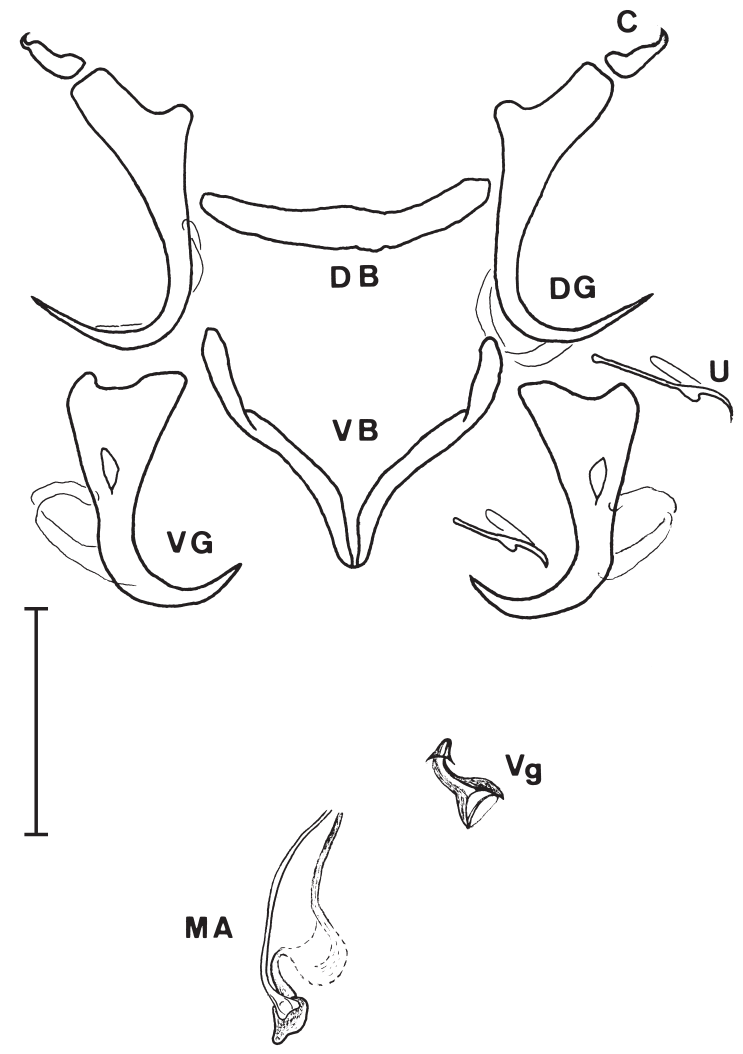

Fig. 2. - Thaparocleidus tacitus $\mathrm{n}$. sp. $\mathrm{C}=$ cuneus; $\mathrm{DB}=$ dorsal transverse bar; $\mathrm{DG}=$ dorsal gripus; $\mathrm{MA}=$ male apparatus; $\mathrm{VB}=$ ventral transverse bar; $\mathrm{VG}=$ ventral gripus; $\mathrm{Vg}=$ vagina; $\mathrm{U}=$ uncinuli. $\mathrm{Bar}=$ $30 \mu \mathrm{m}$.

0.7 (0.1-3). Nearly straight dorsal transverse bar: $\mathrm{x}=$ $36 \pm 1.1$ (33-39), $\mathrm{w}=5 \pm 0.4$ (4-5). Ventral gripus with well marked aperture, regularly arched and strong blade and developed guard: $\mathrm{a}=30 \pm 0.9$ (28-33), $\mathrm{b}=$ $31 \pm 1$ (28-33), $c=3 \pm 0.7(2-5), d=7 \pm 1(4-9), e=$ $9 \pm 1(7-11), \mathrm{L}=7 \pm 0.7(5-8), 1=3 \pm 0.6(2-4) . \mathrm{V}-$ shaped ventral transverse bar: $\mathrm{x}=35 \pm 1.3(32-37), \mathrm{w}=$ $3 \pm 0.3$ (3-4). Thin uncinuli II $=23 \pm 0.8$ (21-25), uncinuli I and III to VII $=19 \pm 2.6(12-23)$. Short and very thin penis with a small basal bulb, poorly developed heel: $\mathrm{Pe}=37 \pm 2(33-41), \mathrm{He}=3 \pm 0.6(2-5)$. Thin and slightly sclerotised accessory piece, attached to basal bulb of the penis, with median part practically non visible: $\mathrm{Ap}=30 \pm 3.4$ (22-36). Short, well sclerotised and thin vagina with one extremity turn inside out and the other one conical: $\mathrm{L}=10 \pm 1.4(7-13), 1=1 \pm 0.2$ (1-2).

\section{Comments}

This new species is easily distinguishable from all described Thaparocleidus from pangasiid fishes in having: - a very thin penis and weakly sclerotised accessory piece (hard to observe);

- almost the same size of both dorsal and ventral gripus.

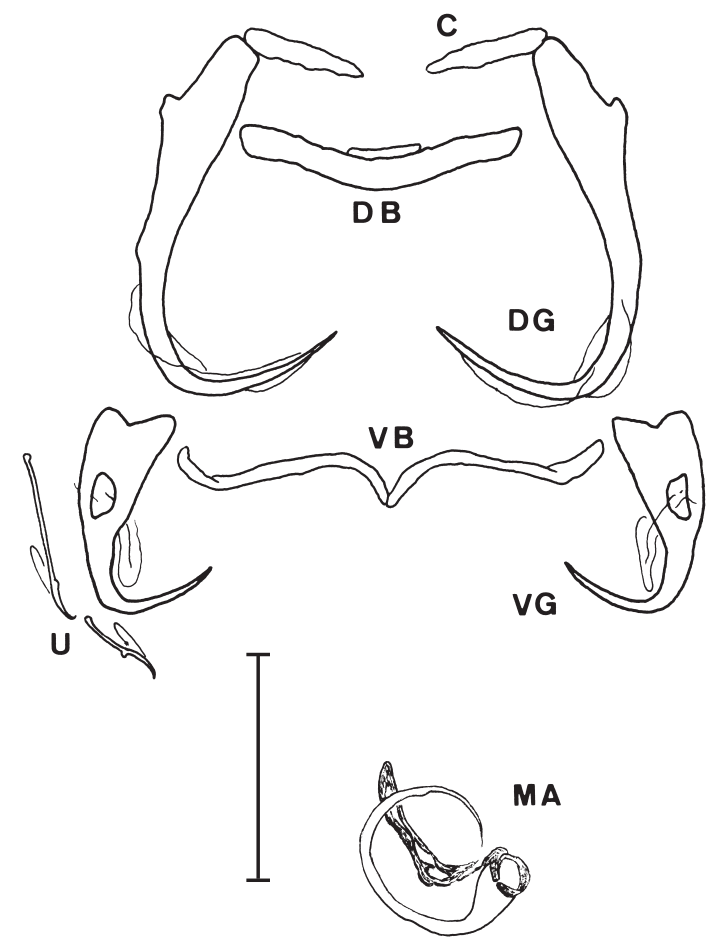

Fig. 3. - Thaparocleidus summagracilis $\mathrm{n}$. sp. $\mathrm{C}=$ cuneus; $\mathrm{DB}=$ dorsal transverse bar; $\mathrm{DG}=$ dorsal gripus; $\mathrm{MA}=$ male apparatus; $\mathrm{VB}=$ ventral transverse bar; $\mathrm{VG}=$ ventral gripus; $\mathrm{U}=$ uncinuli. $\mathrm{Bar}=$ $30 \mu \mathrm{m}$.

Thaparocleidus tacitus $\mathrm{n}$. sp. is proposed because of the poorly visible copulatory organs (tacitus (Latin) $=$ discreet).

\section{THAPAROCLEIDUS SUMMAGRACILIS N. SP. (Fig. 3)}

Type host: Pangasius micronema Bleeker, 1847.

Site: gills.

Type locality: Kapuas River at Sintang (East Kalimantan Province, Borneo Island, Indonesia).

Other records: found on the same host in the Rajang River at Sibu (Sarawak State, Borneo Island, Malaysia) and in the Batang Hari River at Muara Tebo and Jambi (Jambi Province, Sumatra Island, Indonesia).

Material studied: 30 individuals fixed and mounted in Malmberg solution.

Type material: holotype deposited in the Muséum National d'Histoire Naturelle (Paris): n²74 HG; Ti 241. Paratype deposited in the Muséum National d'Histoire Naturelle (Paris): $n^{\circ} 274$ HG; Ti 241bis.

Adults: $747 \pm 107$ (588-983) long, $83 \pm 15$ (49-115) wide at the level of the penis. Pharynx, poorly visible: $37 \pm$ $4.2(28-45)$ wide. Dorsal gripus with blade bent at distal third and poorly marked guard: $\mathrm{a}=47 \pm 1.1(45-49)$, $\mathrm{b}=39 \pm 1.1(36-41), \mathrm{c}=1 \pm 0.3(1-2), \mathrm{d}=11 \pm 0.8(9-$ $13), e=19 \pm 1.4$ (16-22). Straight cuneus without extension: $\mathrm{L}=14 \pm 0.8$ (12-16), $1=4 \pm 0.7$ (3-6). Slightly curved dorsal transverse bar with thickened central por- 
tion on the concave side: $\mathrm{x}=35 \pm 1.3(33-41), \mathrm{w}=$ $6 \pm 0.4$ (5-6). Ventral gripus with well marked aperture, blade bent at the middle and marked guard: $\mathrm{a}=$ $25 \pm 0.7$ (23-26), b = $23 \pm 0.7$ (22-25), c $=2 \pm 0.3$ (12), $d=5 \pm 0.7$ (4-7), e = $13 \pm 0.7$ (11-15), L = $6 \pm 0.5$ (5-8), $1=3 \pm 0.4(2-3)$. V-shaped ventral transverse bar: $\mathrm{x}=29 \pm 1.2(26-32), \mathrm{w}=3 \pm 0.4(2-4)$. Long and thin uncinuli II $=17 \pm 1$ (14-19), long and thin uncinuli I and IV to VII, III shorter $=19 \pm 4(10-25)$. C-shaped penis consisting of a tube getting dramatically thinner at distal quarter, with a large basal bulb: $\mathrm{Pe}=58 \pm 2.3$ (53-64). Very reduced heel: $\mathrm{He}=1 \pm 0.2$ (0.4-1). Simple accessory piece bent at proximal quarter, linked to the basal bulb of the penis: Ap $=23 \pm 1.3$ (21-26). No visible vagina.

\section{Comments}

T. summagracilis $\mathrm{n}$. sp. is easily distinguishable from all described Thaparocleidus from pangasiid fishes in having no extension on the cuneus and a penis getting dramatically thinner at distal quarter.

Thaparocleidus summagracilis $\mathrm{n}$. $\mathrm{sp}$. is named after the shape of the penis (summa (Latin) $=$ end, gracilis $($ Latin $)=$ slender).

\section{THAPAROCLEIDUS PORTENTOSUS N. SP. (Fig. 4A, B)}

Type host: Pangasius micronema Bleeker, 1847.

Site: gills.

Type locality: Kapuas River at Sintang (East Kalimantan Province, Borneo Island, Indonesia).

Other records: found on the same host in the Rajang River at Sibu (Sarawak State, Borneo Island, Malaysia) and in the Batang Hari River at Jambi (Jambi Province, Sumatra Island, Indonesia).

Material studied: 30 individuals fixed and mounted in Malmberg solution.

Type material: holotype deposited in the Muséum National d'Histoire Naturelle (Paris): n 275 HG; Ti 242. Paratype deposited in the Muséum National d'Histoire Naturelle (Paris): n² 275 HG; Ti 242bis.

Adults: $557 \pm 91.9$ (384-741) long, $81 \pm 13.6$ (51-117) wide at the level of the penis. Pharynx: $34 \pm 3.6$ (2740) wide. Dorsal gripus with blade bent at distal third and poorly marked guard: $\mathrm{a}=51 \pm 1.8(47-55), \mathrm{b}=$ $41 \pm 1.6(37-45), c=1 \pm 0.2(0.4-2), d=13 \pm 0.9$ (11$15), e=24 \pm 1.3$ (21-27). Straight cuneus with long extension: $\mathrm{L}=11 \pm 1(9-14), 1=4 \pm 0.4(3-5), \mathrm{e}=11 \pm$ 1.5 (7-15). Slightly curved dorsal transverse bar: $\mathrm{x}=$ $34 \pm 1.8(30-38), \mathrm{w}=5 \pm 0.4(4-6)$. Ventral gripus with marked guard and small aperture: $\mathrm{a}=28 \pm 1.1$ (26-30), $\mathrm{b}=23 \pm 1(21-25), \mathrm{c}=2 \pm 0.4(1-3), \mathrm{d}=8 \pm 0.7$ (710), e $=16 \pm 0.8(13-18), \mathrm{L}=4 \pm 0.5(3-5), 1=1 \pm 0.2$ (1-2). V-shaped ventral transverse bar: $\mathrm{x}=33 \pm 1.6$ (3036), $\mathrm{w}=3 \pm 0.4$ (3-4). Uncinuli $\mathrm{II}=15 \pm 1.3$ (11-18), uncinuli I and III to VII $=16 \pm 2.7(9-20)$. Very long,

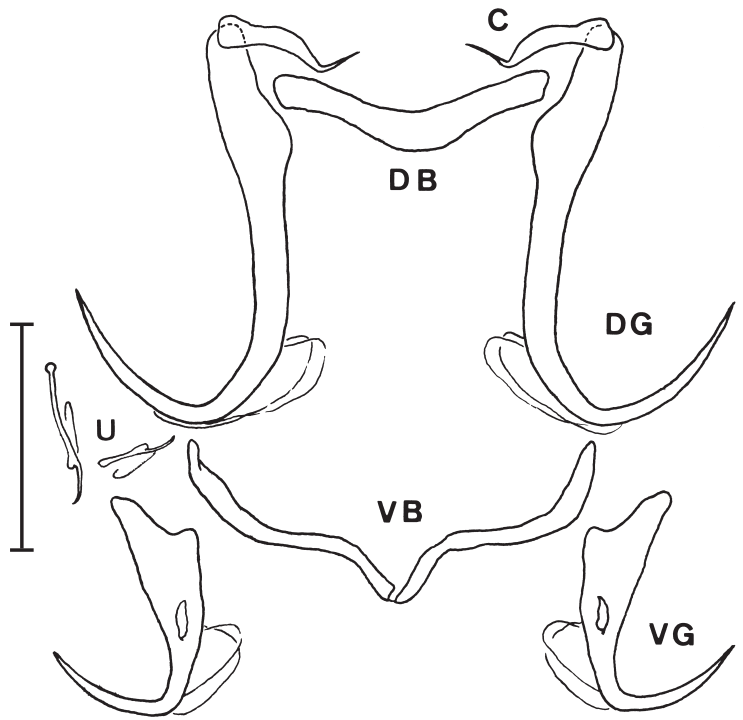

Fig. 4A. - Thaparocleidus portentosus $\mathrm{n} . \mathrm{sp} . \mathrm{C}=$ cuneus; $\mathrm{DB}=$ dorsal transverse bar; $\mathrm{DG}=$ dorsal gripus; $\mathrm{VB}=$ ventral transverse bar; $\mathrm{VG}=$ ventral gripus; $\mathrm{U}=$ uncinuli. $\mathrm{Bar}=30 \mu \mathrm{m}$.

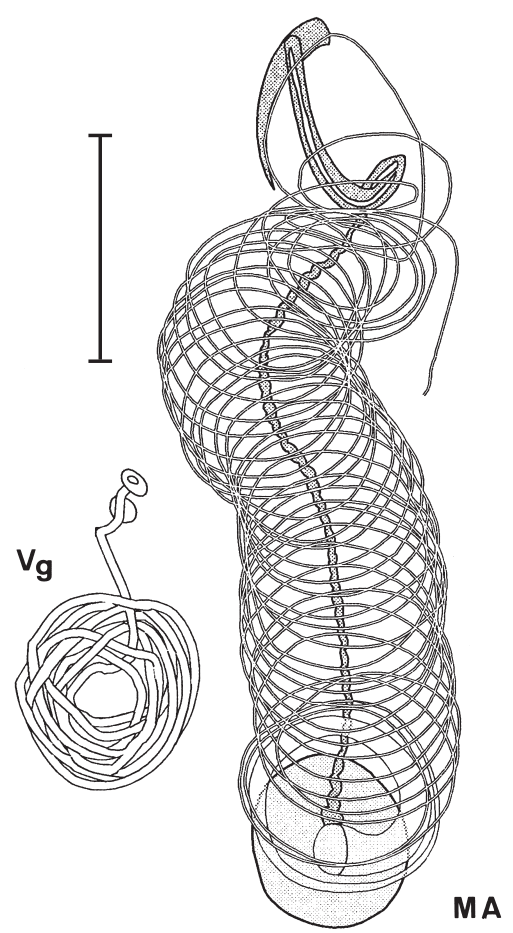

Fig. 4B. - Thaparocleidus portentosus n. sp. MA = male apparatus; $\mathrm{Vg}=$ vagina. $\mathrm{Bar}=30 \mu \mathrm{m}$.

thin and regularly spirally coiled penis (about 35 turns) with marked basal bulb attached on large cupule like structure (diameter $=16 \pm 1.2(13-20))$, spiral is $=19 \pm$ 1.6 (14-23) in diameter. Total length of the penis could be estimated to be more than $2250 \mu \mathrm{m}$. Long accessory piece linked to the basal bulb of the penis, first portion (four fifth) made up of a spirally coiled ribbon, the distal fifth is a J-shaped piece with a gutter like 
depression all along the middle and topped by a thin voile: Ap $=93 \pm 7.5$ (80-108). Spirally coiled (diameter of spiral $=17 \pm 1.6(14-21))$ and thin vagina: $1=1 \pm$ 0.3 (1-2), as the number of turns could not be estimated we could not give a measurement for the vagina.

\section{Comments}

T. portentosus n. sp. is the second species of Thaparocleidus found on pangasiid hosts with a very long, thin and spirally coiled penis (about 35 turns). It may be distinguished from T. euzeti Pariselle, Lim \& Lambert, 2002 mainly by the presence a long accessory piece linked to the basal bulb of the penis ( $v s$. short and not linked), and by the total length of the penis (spiral diameter is $19 v s .61 \mu \mathrm{m}$ and both are 35 turns). Thaparocleidus portentosus $\mathrm{n}$. sp. is named after the length of the penis (portentosus (Latin) $=$ strange).

\section{THAPAROCLEIDUS RUKYANII N. SP. (Fig. 5)}

Type host: Pangasius micronema Bleeker, 1847.

Site: gills.

Type locality: Batang Hari River at Muara Tebo (Jambi Province, Sumatra Island, Indonesia).

Other records: found on the same host in the Kapuas River at Sintang (East Kalimantan Province, Borneo
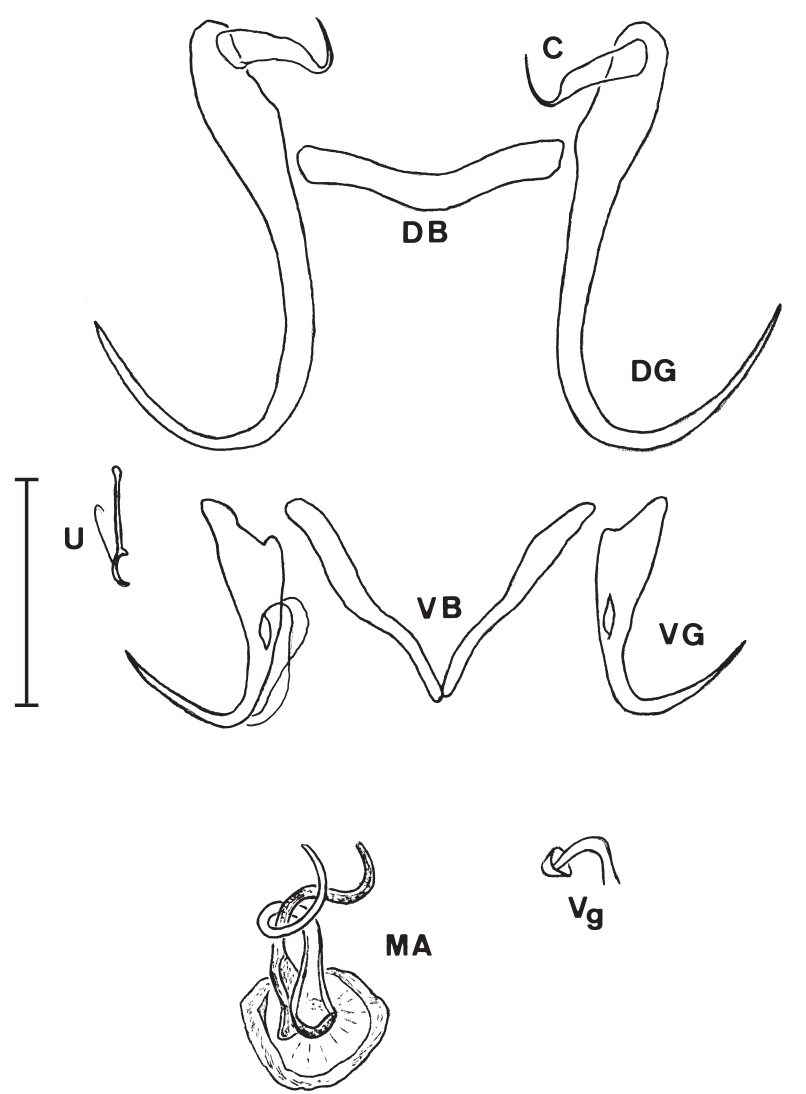

Fig. 5. - Thaparocleidus rukyanii n. sp. $\mathrm{C}=$ cuneus; $\mathrm{DB}=$ dorsal transverse bar; $\mathrm{DG}=$ dorsal gripus; $\mathrm{MA}=$ male apparatus; $\mathrm{VB}=$ ventral transverse bar; $\mathrm{VG}=$ ventral gripus; $\mathrm{Vg}=$ vagina; $\mathrm{U}=$ uncinuli. Bar $=30 \mu \mathrm{m}$.
Island, Indonesia) and in the Rajang River at Sibu (Sarawak State, Borneo Island, Malaysia).

Material studied: 25 individuals fixed and mounted in Malmberg solution.

Type material: holotype deposited in the Muséum National d'Histoire Naturelle (Paris): n 276 HG; Ti 243. Paratype deposited in the Muséum National d'Histoire Naturelle (Paris): n 276 HG; Ti 243bis.

Adults: $615 \pm 81.7$ (484-855) long, $89 \pm 19.5$ (41-134) wide at the level of the penis. Pharynx: $36 \pm 6.4$ (2456) wide. Dorsal gripus with blade bent at distal third and poorly marked guard: $\mathrm{a}=58 \pm 2.3(52-62), \mathrm{b}=$ $45 \pm 1.8$ (39-49), c $=1 \pm 0.2(0.4-1), \mathrm{d}=15 \pm 1.2$ (13$18)$, e $=26 \pm 1.4$ (22-28). Straight cuneus with long and visible extension: $\mathrm{L}=13 \pm 1.3(9-15), 1=5 \pm 0.5$ (4-6), e $=10 \pm 1.7$ (6-16). Slightly V-shaped dorsal transverse bar: $\mathrm{x}=35 \pm 2.1(29-38), \mathrm{w}=5 \pm 0.5$ (4$6)$. Ventral gripus with poorly marked guard, blade bent at proximal third and small apertures: $a=29 \pm$ 0.9 (27-31), $b=23 \pm 0.9$ (21-26), $c=1 \pm 0.3(1-2), d=$ $9 \pm 0.8$ (8-11), e = $17 \pm 0.8$ (16-18). Long and V-shaped ventral transverse bar: $\mathrm{x}=33 \pm 1.4(29-35), \mathrm{w}=4 \pm$ 0.6 (2-4). Uncinuli II $=15 \pm 1.1$ (12-18), uncinuli $\mathrm{I}$ and III to VII $=16 \pm 3$ (8-22). Short and spirally coiled (one turn) penis directly attached on a cupule like structure (diameter $=19 \pm 1.7$ (16-22): $\mathrm{Pe}=42 \pm 3.6$ (35-48). Simple sinuous accessory piece: Ap $=33 \pm 3.6$ (20-37). Thin and curved vagina with one extremity turn inside out: $\mathrm{L}=16 \pm 2.7$ (11-22), $1=1 \pm 0.3(1-2)$.

Comments

T. rukyanii $\mathrm{n}$. sp. belongs to the group of Thaparocleidus with a spirally coiled penis attached to a cupulelike structure: T. brevicochleus Pariselle, Lim \& Lambert, 2001; T. kapuasensis Pariselle, Lim \& Lambert, 2001, T. euzeti Pariselle, Lim \& Lambert, 2002; T. levangi Pariselle, Lim \& Lambert, 2004; T. slembroucki Pariselle, Lim \& Lambert, 2004 and T. portentosus n. sp. Among these, only two also possess cuneus with long and visible extension (10 $\mu \mathrm{m}$ long or more): T. kapuasensis and T. portentosus n. sp. T. rukyanii n. sp. is easily distinguishable by the length and number of turn in the penis ( $42 \mu \mathrm{m}$ and $1 v$ s. $115 \mu \mathrm{m}$ and 2 or more than $2250 \mu \mathrm{m}$ and about 35 ).

Thaparocleidus rukyanii $\mathrm{n}$. sp. is named for our late lamented colleague Dr Ahmad Rukyani, former Director of Fish Diseases and Environment at the Directorate General of Fisheries (Jakarta, Indonesia).

\section{THAPAROCLEIDUS DURANDI N. SP. (Fig. 6A, B)}

Type host: Pangasius micronema Bleeker, 1847.

Site: gills.

Type locality: Kapuas River at Sintang (East Kalimantan Province, Borneo Island, Indonesia).

Other records: found on the same host in the Rajang River at Sibu (Sarawak State, Borneo Island, Malaysia) 


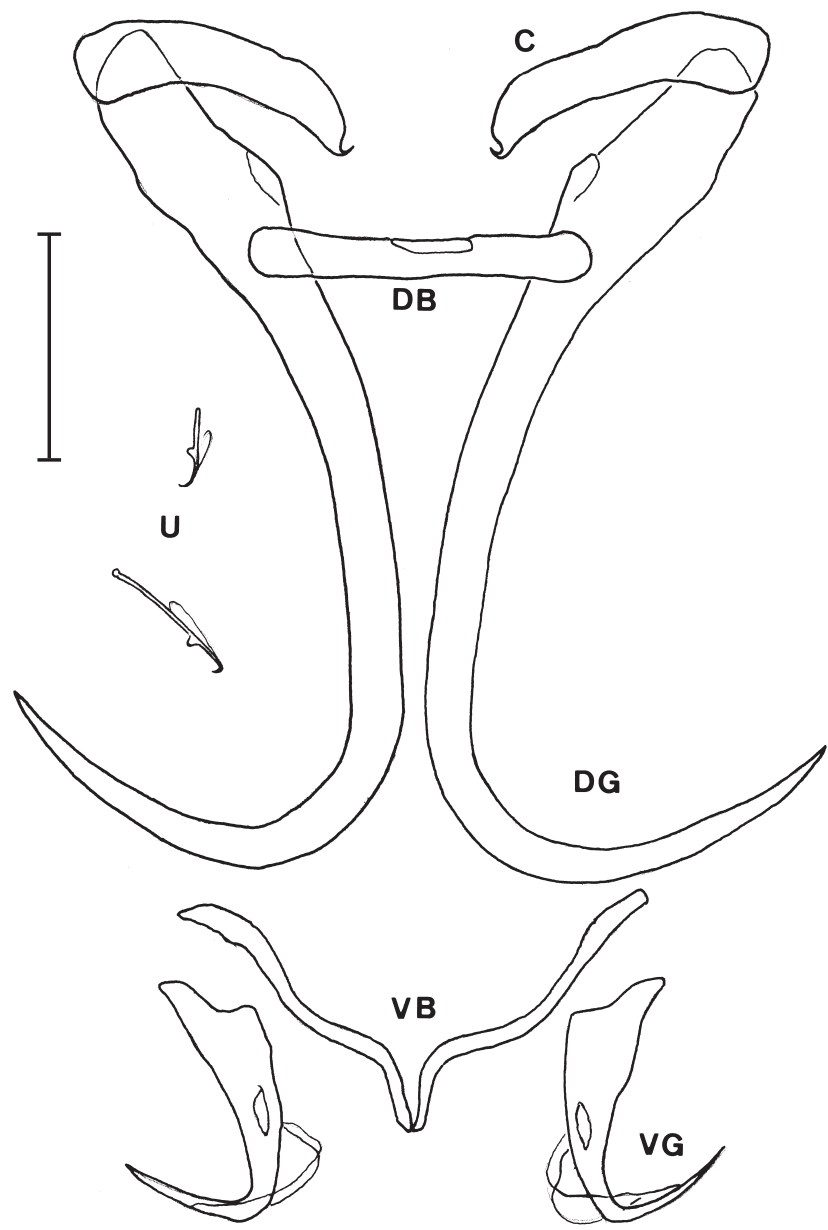

Fig. 6A. - Thaparocleidus durandi $\mathrm{n}$. sp. $\mathrm{C}=$ cuneus; $\mathrm{DB}=$ dorsal transverse bar; $\mathrm{DG}=$ dorsal gripus; $\mathrm{VB}=$ ventral transverse bar; $\mathrm{VG}=$ ventral gripus; $\mathrm{U}=$ uncinuli. $\mathrm{Bar}=30 \mu \mathrm{m}$.
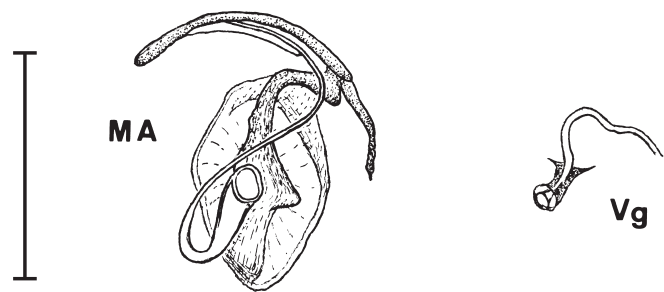

Fig. 6B. - Thaparocleidus durandi $\mathrm{n}$. sp. MA = male apparatus; $\mathrm{Vg}=$ vagina. $B a r=30 \mu \mathrm{m}$.

and in the Batang Hari River at Muara Tebo and Jambi (Jambi Province, Sumatra Island, Indonesia).

Material studied: 19 individuals fixed and mounted in Malmberg solution.

Type material: holotype deposited in the Muséum National d'Histoire Naturelle (Paris): n 277 HG; Ti 244. Paratype deposited in the Muséum National d'Histoire Naturelle (Paris): n 277 HG; Ti 244bis.

Adults: $772 \pm 204.2$ (507-1200) long, $97 \pm 23.9$ (57-140) wide at the level of the penis. Pharynx: $40 \pm 6.4$ (2750) wide. Large dorsal gripus with blade bent at distal third and poorly marked guard: $\mathrm{a}=107 \pm 7$ (90-119), $\mathrm{b}=91 \pm 5.8(78-100), \mathrm{c}=2 \pm 0.6(1-3), \mathrm{d}=21 \pm 1.9$ $(17-24), \mathrm{e}=43 \pm 3$ (37-49). Large and slightly curved cuneus with very short extension: $\mathrm{L}=37 \pm 2.3$ (31$41), 1=10 \pm 1$ (7-12), e $=3 \pm 1.3$ (1-7). Strong and straight dorsal transverse bar: $\mathrm{x}=42 \pm 1.6(39-45), \mathrm{w}=$ $5 \pm 0.5$ (3-6). Ventral gripus with narrow aperture and poorly marked guard: $\mathrm{a}=33 \pm 0.9(31-35), \mathrm{b}=27 \pm$ 0.9 (25-29), $\mathrm{c}=1 \pm 0.4(1-2), \mathrm{d}=10 \pm 0.8$ (8-12), e = $17 \pm 1.1$ (14-19), $\mathrm{L}=6 \pm 0.8$ (4-8), $1=1 \pm 0.2$ (1-2). Long V-shaped ventral transverse bar: $\mathrm{x}=43 \pm 2$ (40$47), \mathrm{w}=3 \pm 0.5$ (3-4). Thin uncinuli II $=15 \pm 1$ (1317), uncinuli I and III to VII $=16 \pm 3.4$ (8-21). Thin curved penis with a poorly marked basal bulb, directly attached to a cupule-like structure $(24 \pm 2.4(20-28)$ at its width), no visible heel: $\mathrm{Pe}=69 \pm 5.4(52-77)$. Sinuous accessory piece linked to the cupule-like structure near to the penis attachment: Ap $=66 \pm 10$ (4581). Thin and sinuous vagina, one extremity turned inside out: $\mathrm{L}=23 \pm 3.1$ (18-29), $1=1 \pm 0.2$ (1-1).

\section{Comments}

T. durandi n. sp. belongs to the group characterised by the presence of a cupule-like structure to which the penis is attached. This new species is easily distinguishable by the size of dorsal haptorial sclerotised pieces (e.g. dorsal gripus $\mathrm{a}=107 \mu \mathrm{m}$ and cuneus $\mathrm{L}=37 \mu \mathrm{m}$ ), largest sizes observed in this group.

The name Thaparocleidus durandi $\mathrm{n}$. sp. is proposed in honour of Dr Jean-René Durand, fish biologist from IRD (ex ORSTOM).

\section{Thaparocleidus LEBRUNAE N. SP. (Fig. 7A, B)}

Type host: Pangasius micronema Bleeker, 1847. Site: gills.

Type locality: Rajang River at Sibu (Sarawak State, Borneo Island, Malaysia).

Other records: found on the same host in the Kapuas River at Sintang (East Kalimantan Province, Borneo Island, Indonesia), in the Batang Hari River at Muara Tebo (Jambi Province, Sumatra Island, Indonesia) and on Pangasius polyuranodon (only two individuals among 988 collected, see Pariselle et al., $2004 \mathrm{~b}$ and "Conclusions" below) in the Barito River at Buntok (Central Kalimantan Province, Borneo Island, Indonesia).

Material studied: 20 individuals fixed and mounted in Malmberg solution.

Type material: holotype deposited in the Muséum National d'Histoire Naturelle (Paris): n²78 HG; Ti 245. Paratype deposited in the Muséum National d'Histoire Naturelle (Paris): $\mathrm{n}^{\circ} 278 \mathrm{HG}$; Ti 245bis.

Adults: $616 \pm 101.6$ (446-782) long, $96 \pm 21.8$ (64-132) wide at the level of the penis. Pharynx: $43 \pm 7$ (3257) at its width. Dorsal gripus with blade bent at distal third and marked guard: $\mathrm{a}=47 \pm 2(43-51), \mathrm{b}=38 \pm 2$ 


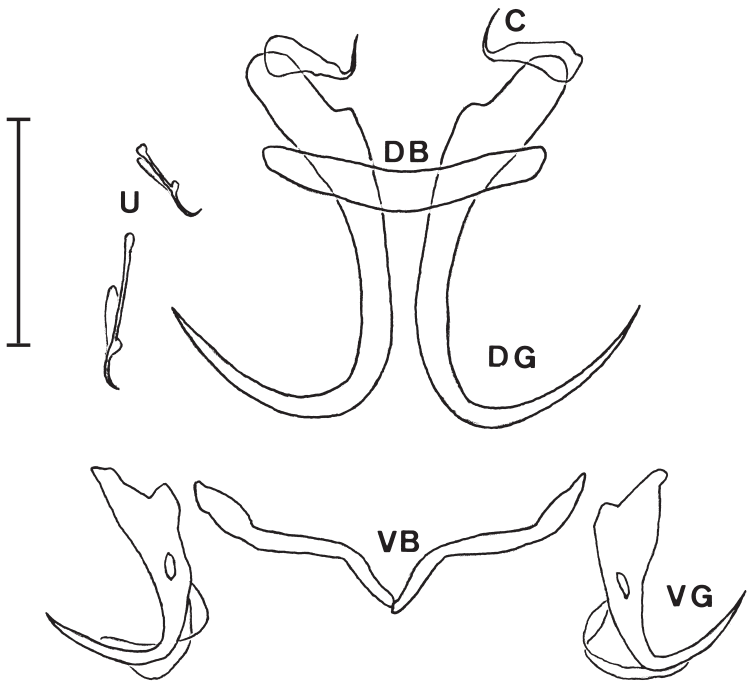

Fig. 7A. - Thaparocleidus lebrunae $\mathrm{n} . \mathrm{sp} . \mathrm{C}=$ cuneus; $\mathrm{DB}=$ dorsal transverse bar; $\mathrm{DG}=$ dorsal gripus; $\mathrm{VB}=$ ventral transverse bar; $\mathrm{VG}=$ ventral gripus; $\mathrm{U}=$ uncinuli. $\mathrm{Bar}=30 \mu \mathrm{m}$.

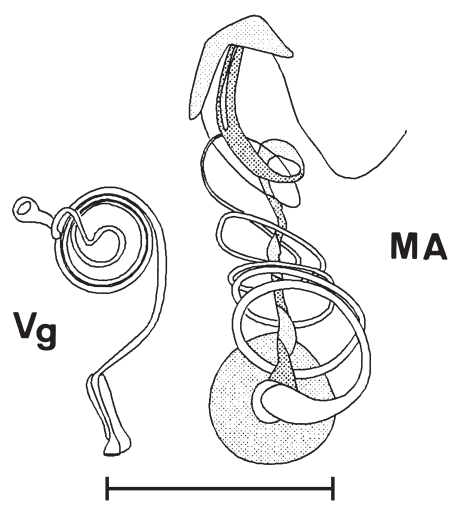

Fig. 7B. - Thaparocleidus lebrunae n. sp. $\mathrm{MA}=$ male apparatus; $\mathrm{Vg}=$ vagina. $\mathrm{Bar}=30 \mu \mathrm{m}$.

(33-42), $c=1 \pm 0.4(1-3), d=12 \pm 1(10-14), e=25 \pm$ 1.1 (23-28). Small cuneus with thin extension: $\mathrm{L}=10 \pm$ 0.9 (8-12), $1=4 \pm 0.6$ (3-5), e $=6 \pm 1.3$ (3-8). Slightly V-shaped dorsal transverse bar: $\mathrm{x}=34 \pm 1.9$ (30-37), $\mathrm{w}=5 \pm 0.7$ (4-6). Ventral gripus with small aperture and guard: $\mathrm{a}=26 \pm 1(25-29), \mathrm{b}=21 \pm 0.9$ (20-23), $\mathrm{c}=1 \pm 0.3(1-2), \mathrm{d}=8 \pm 0.7(7-10), \mathrm{e}=16 \pm 1$ (1317), $\mathrm{L}=3 \pm 0.5(2-4), 1=1 \pm 0.4$ (1-2). V-shaped ventral transverse bar: $\mathrm{x}=29 \pm 1.6(26-33), \mathrm{w}=4 \pm 0.5$ (3-4). Thin uncinuli II $=15 \pm 1.5$ (11-18), uncinuli I and III to VII $=17 \pm 3.6$ (9-22). Long, thin and spirally coiled penis (4-5 turns) attached to a cupule-like structure $($ diameter $=19 \pm 2.2(16-23)): \mathrm{Pe}=271 \pm 20.2$ (231304). Long and thin accessory piece, two first third straight and shape as a screw with a large thread, linked by a loop to the last third, this part, C-shaped and stronger with a gutter depression, is topped by a thin piece, the accessory piece is attached near to the basal bulb of the penis: Ap $=66 \pm 5.3$ (56-75). Long, thin and spirally coiled ( 3 turns) vagina: $\mathrm{L}=142 \pm 15.9$ (113-176), $1=1 \pm 0.2$ (0.8-1.3).

Comments

T. lebrunae n. sp. belongs to the group with spirally coiled penis attached to a cupule-like structure: T. brevicochleus Pariselle, Lim \& Lambert, 2001; T. kapuasensis Pariselle, Lim \& Lambert, 2001; T. euzeti Pariselle, Lim \& Lambert, 2002; T. levangi Pariselle, Lim \& Lambert, 2004; T. slembroucki Pariselle, Lim \& Lambert, 2004; T. portentosus n. sp. and T. rukyanii n. sp. In this group only two species also possess a spirally coiled vagina (T. euzeti and T. portentosus). T. lebrunae n. sp. could be easily distinguished by the number of turns described by the penis ( $4-5$ vs. 35 for both T. euzeti and T. portentosus).

The name Thaparocleidus lebrunae n. sp. is proposed to acknowledge Dr. Nathalie Le Brun who helped in drawing the figures.

\section{CONCLUSIONS}

The only two T. lebrunae n. sp. individuals found on $P$. polyuranodon are morphologically similar to those collected from $P$. micronema, but their measurements are always (genitalia and haptor) smaller. As no P. micronema could be sampled in the same location nothing could be concluded about their specific identity (lateral transfer, rare sister species?).

T. brevicochleus and T. sinespinae, initially recorded only from Kalimantan (South part of Borneo Island) on $P$. humeralis (the two parasite species) from Kapuas River and on $P$. polyuranodon (T. brevicochleus only) from the Barito River, were found on $P$. micronema from all the sampled rivers (Sumatra, North and South parts of Borneo Island) (nobis). As the host species are not closely related (see Pouyaud et al., 2000) and as the locations are distant and well separated, we cannot conclude anything about their specific identity (lateral transfer or inheritance from ancestor?).

As all the parasitic species from P. micronema quoted in this paper were recorded from all the locations (North and South Borneo, Central Sumatra) without evidence of morphometrical differences; we may conclude that the isolation of host populations is not ancient (Isolation of host populations is effective as P. micronema is strictly from freshwater and as rivers from North and South Borneo are not connected). Otherwise, we would probably have found differences among parasitic populations (see "Conclusions" in Pariselle et al., 2002b).

The present six new species bring the number of monogenean parasitic species described on 19 species of pangasiids (P. bocourti, P. djambal, P. elongatus, P. gigas, $P$. humeralis, $P$. hypophthalmus, $P$. kinabatanganensis, P. krempfi, P. kunyit, P. lithostoma, P. mahakamensis, 
P. mekongensis, P. micronema, P. nasutus, P. nieuwenhuisii, $P$. pangasius, $P$. polyuranodon, $P$. rheophilus and P. sabahensis) to 46.

\section{ACKNOWLEDGEMENTS}

T This work is part of a project on the "characterisation utilisation and maintenance of biological diversity for the diversification and sustainability of catfish culture in Southeast Asia" supported by the European Commission (grant IC18-CT96-0043).

Drawings by Dr Nathalie Le Brun.

\section{REFERENCES}

Euzet L. \& Prost M. Report of the meeting on Monogenea: problems of systematics, biology and ecology. In: Slusarski W. (Eds) Review of advances in parasitology. Warsaw: P.W.N. Polish Scientific Publishers, 1981, pp. 1003-1004.

Gussev A.V. In: Bychovskaya-Pavlovskaya I.E. et al. (Eds) [Key to parasites of freshwater fish of the USSR.] MoscowLeningrad: Academiya Nauk SSSR, 1962, 919 pp. (In Russian: English translation IPST, Ser. No. 1136, Jerusalem, 1964).

Lim L.H.S. Silurodiscoides Gussev, 1961 (Monogenea: Ancyrocephalidae) from Pangasius sutchi Fowler, 1931 (Pangasiidae) cultured in Peninsular Malaysia. Raffles Bulletin of Zoology, 1990, 38, 55-63.

Lim L.H.S. Thaparocleidus Jain, 1952, the senior synonym of Silurodiscoides Gussev, 1976 (Monogenea: Ancyrodiscoidinae). Systematic Parasitology, 1996, 35, 207-215.

Lim L.H.S., Timofeeva T.A. \& GiBson D.I. Dactylogyridean monogeneans of the siluriform fishes of the Old World. Systematic Parasitology, 2001, 50, 159-197.

Malmberg G. [On the occurrence of Gyrodactylus on Swedish fishes.] Skrifterutgivna av Sodra Sveriges Fiskeriforening, (1956), 1957, pp. 19-76 (In Swedish, with description of species and a summary in English).

N'Douba V., LAmberT A. \& Euzet L. Gill parasites of the genus Quadriacanthus Paperna, 1961 from Heterobranchus longifilis and $H$. isopterus with description of seven new species from Côte d'Ivoire, West Africa. Systematic Parasitology, 1999, 44, 105-118.

Pariselle A. \& Euzet L. Gill parasites of the genus Cichlidogyrus Paperna, 1960 (Monogenea, Ancyrocephalidae) from Tilapia guineensis (Bleeker, 1862), with descriptions of six new species. Systematic Parasitology, 1995, 30, 187-198.

Pariselle A., Lim L.H.S. \& LAMBERT A. Monogeneans from Pangasiidae (Siluriformes) in Southeast Asia: I. Five new species of Thaparocleidus Jain, 1952 (Ancylodiscoidinae) from Pangasius pangasius, $P$. kinabatanganensis, $P$. rheophilus and P. nieuwenhuisii. Parasite, 2001a, 8, 127-135

Pariselle A., Lim L.H.S. \& LAmberT A. Monogeneans from Pangasiidae (Siluriformes) in Southeast Asia: II: Four new species of Thaparocleidus Jain, 1952 (Ancylodiscoidinae) from Pangasius humeralis. Parasite, 2001b, 8, 317-324.
Pariselle A., Lim L.H.S. \& LAmBert A. Monogeneans from Pangasiidae (Siluriformes) in Southeast Asia: III: Five new species of Thaparocleidus Jain, 1952 (Ancylodiscoididae) from Pangasius bocourti, P. djambal and P. hypophthalmus. Parasite, 2002a, 9, 207-217.

Pariselle A., Lim L.H.S. \& LAmBert A. Monogeneans from Pangasiidae (Siluriformes) in Southeast Asia: IV. Five new species of Thaparocleidus Jain, 1952 (Ancylodiscoididae) from Pangasius krempfi, P. kunyit, P. mekongensis and P. sababensis. Parasite, 2002b, 9, 315-324.

Pariselle A., Lim L.H.S. \& LAMberT A. Monogeneans from Pangasiidae (Siluriformes) in Southeast Asia: V: Five new species of Thaparocleidus Jain, 1952 (Ancylodiscoididae) from Pangasius nasutus. Parasite, 2003, 10, 317-323.

Pariselle A., Euzet L. \& Lambert A. Monogeneans from Pangasiidae (Siluriformes) in Southeast Asia: VI. Pangasitrema camillae n. g. n. sp. (Monogenea, Ancylodiscoididae), from Pangasius polyuranodon., Parasite, 2004a, 11, 149-152.

Pariselle A., Lim L.H.S. \& Lambert A. Monogeneans from Pangasiidae (Siluriformes) in Southeast Asia: VII. Six new specific species of Thaparocleidus Jain, 1952 (Ancylodiscoididae) from Pangasius polyuranodon. Parasite, 2004b, 11, 365-372.

Pariselle A., Lim L.H.S. \& LAmBert A. Monogeneans from Pangasiidae (Siluriformes) in Southeast Asia: VIII. Four new species of Thaparocleidus Jain, 1952 (Ancylodiscoididae) from Pangasius polyuranodon and P. elongatus. Parasite, 2005a, 12, 23-29.

Pariselle A., Lim L.H.S. \& LAMbert A. Monogeneans from Pangasiidae (Siluriformes) in Southeast Asia: IX. Two new species of Thaparocleidus Jain, 1952 (Ancylodiscoididae) from Pangasius mahakamensis. Parasite, 2005b, 12, 325-330.

Pouyaud L., Teugels G.G., Gustiano R. \& Legendre M. Contribution to the phylogeny of pangasiid catfishes based on allozymes and mitochondrial DNA. Journal of Fish Biology, 2000, 56, 1509-1538.

TRIPATHI Y.R. Monogenetic trematodes from fishes in India. Indian Journal of Helminthology, 1957, 9, 1-149.

Reçu le 10 novembe 2005 Accepté le 9 mai 2006 